\title{
Ginsenoside contents and antioxidant activities of cultivated mountain ginseng (Panax ginseng C.A. Meyer) with different ages
}

\author{
Beom-Gyun Jeong ${ }^{1,2}$, Gil-Rak Jung ${ }^{3}$, Min Sik Kim ${ }^{1}$, Hyun-Gyu Moon ${ }^{1}$ \\ $\mathrm{Su}^{-J i n}$ Park $^{1}$, Jiyeon Chun ${ }^{1 *}$ \\ ${ }^{1}$ Department of Food Science and Technology, Sunchon National University, Suncheon 57922, Korea \\ ${ }^{2}$ Department of Food Science and Technology, University of Georgia, Athens, GA 30602, USA \\ ${ }^{3}$ Agricultural Technology Center, Tongyeong 53021, Korea
}

\section{산양삼의 년근별 진세노사이드 함량 및 항산화 활성}

\author{
정 범균 ${ }^{1,2}$ - 정길락 ${ }^{3} \cdot$ 김민식 ${ }^{1} \cdot$ 문현규 $^{1} \cdot$ 박수진 $^{1} \cdot$ 천지연 ${ }^{1 *}$ \\ ${ }^{1}$ 순천대학교 식품과학부 식품공학전공, ${ }^{2}$ 조지아대학교 식품공학과, ${ }^{3}$ 통영 농업기술센터 농업기술과
}

\begin{abstract}
The morphological, nutritional, and functional characteristics of cultivated mountain ginseng (Panax ginseng C.A. Meyer, CMG) with different ages $(3,5,7$, and 9 years old) were investigated. Three-year-old CMG (3-CMG) was significantly smaller, shorter, and lighter than 5-CMG while there is no significant difference in length, thickness, and weight among 5-, 7-, and 9-CMGs. On the other hand, functional properties of CMG highly varied with the cultivation age. Moisture content of CMGs with different ages decreased with age except for 9-CMG whereas crude fat and protein contents increased with age. DPPH and ABTS radical scavenging activities were highest in 9-CMG (82.4 $\mathrm{\mu g} \mathrm{GAE} / \mathrm{g}$ and $723.6 \mu \mathrm{g} \mathrm{AAE} / \mathrm{g}$, respectively) while reducing poser was highest in 3-CMG (411.7 GAE/g). Xanthine oxidase inhibition activity of 9-CMG (17.24 $\mathrm{ug} \mathrm{AAE} / \mathrm{g})$ was 1.5 times higher than that of 3-CMG. Acidic polysaccharide content was highest in 7-CMG (3,298 mg GAAE/g) but lowest in 3-CMG. Total polyphenol and flavonoid contents were highest in 5- and 7-CMG, respectively, and decreased with the cultivation period. Total ginsenoside content of CMG increased with the cultivation period. $R b_{1}$ and Re were predominant ginsenosides for all CMGs, accounting for about $\mathbf{5 0 \%}$ of total ginsenoside content. $\mathrm{Rb}_{1}$ of 9-CMG was about four times higher than that of 3-CMG. Compound $\mathrm{K}$ was found in all CMGs, but it took less than $0.1 \%$ of total ginsenoside content.
\end{abstract}

Key words : cultivated mountain ginseng, age, ginsenoside, antioxidant activity, xanthine oxidase inhibition activity

\section{서 론}

인삼류는 전통적으로 잘 알려진 약용 식물 중 하나로 30종 이상의 사포닌(ginsenoside), 산성다당체, 폴리아세틸 렌, 알칼로이드, 페놀성화합물, 고미신(gomisin-A, -N) 등 다양한 기능성 성분들이 존재하며, 이에 따라 기억력 감퇴

*Corresponding author. E-mail : cjyfall@sunchon.ac.kr Phone : 82-61-750-3258, Fax : 82-61-750-3250

Received 6 November 2018; Revised 26 December 2018; Accepted 27 December 2018.

Copyright (c) The Korean Society of Food Preservation. All rights reserved.
개선 및 공간인지능력 향상, 암 예방 및 항암활성, 항당뇨, 간기능 항진, 혈압조절, 항스트레스, 항산화 등 우수한 기능 성을 나타내는 것으로 알려져 있다(1-9). 이러한 건강 우수 성으로 인하여 재배된 인삼과 이를 이용하여 증숙 및 건조 해 만든 홍삼은 건강보조식품으로 널리 이용되고 있을 뿐만 아니라(10) 일반 가공식품 산업에서 다양한 식품류로의 활 용을 통하여 부가가치를 창출하고 있다(11). 인삼의 이러한 넓은 활용으로 인하여 인삼의 재배조건 및 생육특성에 관한 많은 연구가 수행되어 왔고 이에 따른 품질지표 및 재배기 간에 따른 등급 체계등도 이미 설정되어 산업화에 활용되고 있다 $(12,13)$

산양삼(cultivated mountain ginseng 또는 wild-simulated 
ginseng)은 인삼을 야생에서 발아하여 성장한 종자나 어린 뿌리를 인위적으로 산에 파종하여 야생상태로 재배한 삼을 가리키며 학명은 Panax ginseng C.A. Meyer로 인삼의 학명 과 같다 $(14,15)$. 산양삼은 형태학적으로 산삼에 비해 줄기 에서 뿌리가 시작하는 뇌두 부분이 길어 장뇌삼으로도 불리 며, 인삼에 비해서는 몸통이 가늘고 길며 강한 향을 가지는 특징을 보인다 $(16,17)$. 또한, 산양삼은 재배 인삼에 비하여 인삼 사포닌인 ginsenoside 함량이 높은 것으로 알려져 건강 적 효능이 뛰어남을 인정받고 있지만 $(15,18)$, 인삼에 비하 여 재배가 어렵고 가격이 비싸기 때문에 그 동안 대부분 약재에 국한하여 사용되어 왔을 뿐 가공을 통한 일반식품류 나 건강식품류로의 산업화는 거의 시도되지 못하였기 때문 에 국내외 적으로 산양삼에 관한 기초 및 가공 연구 자료가 거의 전무한 실정이다. 최근, 산양삼이 자연친화적으로 재 배된 기능성 식물자원이란 인식으로 인하여 국내에서 생산 량이 2014년에 비하여 2016년에 $13 \%$ 증가하였으며 이로 인한 생산 단가의 하락은 산양삼 자원에 대한 가공 산업화 및 6차 산업화로의 요구가 확산되고 있어 이를 위한 과학적 데이터베이스 구축 및 연구 자료의 축적이 시급한 실정이다 (19-21).

인삼류의 대표 기능성 성분인 진세노사이드는 섭취 후 장내 미생물에 의해 분해되어 다양한 대사체로 변화되는데 체내 흡수와 대사과정은 사포닌의 종류에 따라 달라진다. $\mathrm{Rb}_{1}, \mathrm{Rb}_{2}, \mathrm{Rh}_{2}, \mathrm{Rc}, \mathrm{Rd}$ 등의 경우, 위액 중에서 20 번 탄소 위치의 당쇄가 절단되면 $\mathrm{Rg}_{3}$ 로 변환되어 흡수되는 것으로 알려져 있으며, $\mathrm{Rb}_{1}, \mathrm{Rb}_{2}, \mathrm{Rb}_{3}, \mathrm{Rc}, \mathrm{Rd}$ 등이 $\mathrm{Rg}_{3}$ 의 전구체인 것으로 보고되어 있고, $\mathrm{Rb}_{1}$ 은 $\mathrm{Rd}$ 가 $\mathrm{F}_{2}$ 로 전환된 후 compound $\mathrm{K}$ 로 전환되는 것으로 알려져 있다 $(22,23)$. 특히 $\mathrm{Rb}_{1}, \mathrm{Rb}_{2}, \mathrm{Rc}, \mathrm{Rd}$ 등의 대사산물인 compound $\mathrm{K}$ 는 종양 형성 을 막고 암세포의 침입을 억제함으로써 악성 종양의 생성이 나 암의 전이를 막는다(24). 인삼류의 진세노사이드의 구조 에 따라 다양한 약리적 효능을 보이는 것으로 알려져 있는 데 이들의 조성과 함량은 인삼의 종류, 부위, 재배기간, 재배 지 등에 따라서 차이가 있는 것으로 알려져 있다(25). 인삼 류의 특성에 따른 다양한 연구가 진행되어 온 것과 달리 산양삼에 대한 기초 자료는 거의 이루어지지 못한 실정이 며, 항당뇨, 혈압강화, 항산화, 비만 등에 대한 효능에 관한 연구도 아직 초기 단계이다. 재배 인삼에 비해 인지도가 낮고 가치가 저평가 되어 있는 산양삼을 고부가 산업화하기 위해서는 원료의 특성, 가공 적성, 건강 기능적 가치 등에 대한 기초적 선행 연구를 통한 기초 데이터베이스를 구축하 는 것이 선행되어야 하며 이는 다양한 가공 산업화를 위한 확대 연구를 가속화할 수 있을 것으로 보인다.

본 연구에서는 함양산 산양삼을 생육기간별로 수집하고 이들의 이화학적, 영양적 및 기능적 특성을 비교 분석하여 산양삼 고차 산업화를 위한 기초 데이터베이스를 구축하고 자 하였다.

\section{재료 및 방법}

시 약

분석에 사용된 ginsenoside 표준품 $\left(\mathrm{Rb}_{1}, \mathrm{Rb}_{2}, \mathrm{Rc}, \mathrm{Rd}, \mathrm{Re}\right.$, $\mathrm{Rf}, \mathrm{Rg}_{1}, \mathrm{Rg}_{2}, \mathrm{Rh}_{2}$, 및 $\mathrm{Rg}_{3}$ ), quercetin, galacturonic acid, gallic acid, L-ascorbic acid 표준품과 Folin-Ciocalteu's phenol reagent와 1,1-diphenyl-2-picrylhydrazyl(DPPH)은 SigmaAldrich Chemical Co.(St. Louis, MO, USA)에서 구입하였으며, ginsenoside $\mathrm{F}_{2}$ 와 compound $\mathrm{K}$ 표준품은 앰보연구소(AMBO Institute, Daejeon, Korea)에서 구입하였다. 기타 사용된 시 약은 특급 및 HPLC 등급을 사용하였다.

\section{산양삼 시료}

산양삼은 경남 함양군 서하면에서 재배 후 국내산 특별 관리임산물 품질검사를 통과한 $3,5,7,9$ 년근을 구입하여 사용하였다. 구입한 시료는 흐르는 물에 세척 후 표면의 수분이 제거될 때까지 실온에서 자연 음건하였으며 시료의 형태학적 특성을 관찰하고 수분 함량을 측정한 다음 $-70^{\circ} \mathrm{C}$ 에서 동결 보관하였다. 분석을 위한 시료는 동결건조기 (FDT-12012, Operon, Kimpo, Korea)에서 건조시킨 후 분쇄 기(HGBSSSS6, Waring, Torrington, CT, USA)로 분쇄한 다 음 80 mesh standard sieve(Chunggye Co., Seoul, Korea)를 통과한 분말을 $-70^{\circ} \mathrm{C}$ 에서 보관하며 분석 시료로 사용하였 다.

\section{산양삼의 형태 관찰 및 수분함량 측정}

산양삼 원물은 무작위로 뿌리 10개를 선정하여 Fig. 1과 같이 총 길이, 원뿌리, 뇌두를 구분한 다음 각각의 길이와 두께를 측정하였다. 총길이는 $50 \mathrm{~cm}$ 줄자를 이용하여 측정 하였으며, 원뿌리 및 뇌두의 길이와 두께는 캘리퍼스 (530-101, Mitutoyo, Kawasaki, Japan)를 이용하여 측정하였

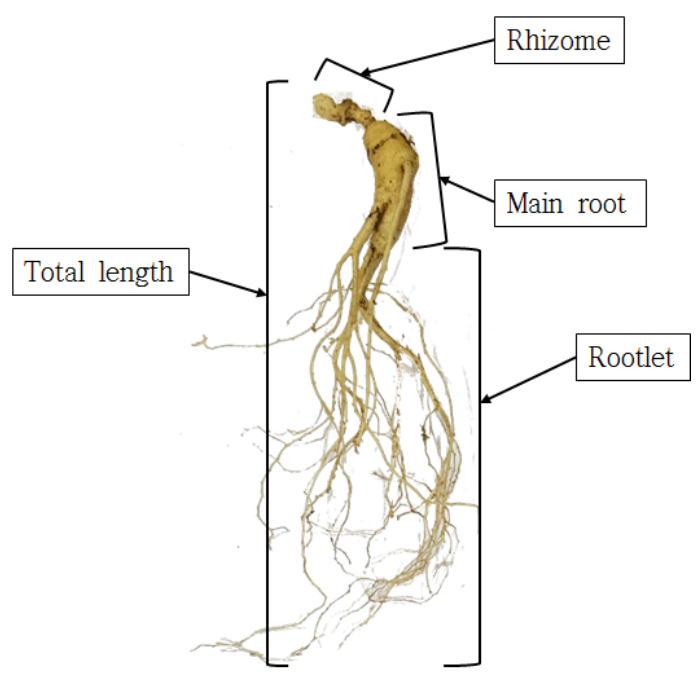

Fig. 1. Part names of cultivated mountain ginseng. 
다. 무게는 전자저울을 이용하여 소수점 두 번째 자리까지 측정하였다. 수분함량은 시료를 $5 \mathrm{~mm}$ 두께로 잘게 세절한 뒤, $1 \mathrm{~g}$ 을 적외선수분함량측정기(MB45, OHAUS, Parsippany, $\mathrm{NJ}, \mathrm{USA}$ )를 이용하여 3회 반복하여 측정하였다.

\section{일반성분 분석}

일반성분은 $\mathrm{AOAC}$ 법(26)에 따라 분석하였다. 조회분은 직접 회화법, 조단백은 Kjeldahl법에 따라 측정된 질소량에 질소 계수 6.25 를 곱하여 산출하였으며, 조지방 함량은 Soxhlet 추출법으로 분석하였다.

\section{Ginsenoside 함량 분석}

Ginsenoside 성분의 추출은 Lee 등(27)의 방법을 일부 변형하여 추출하였다. 동결건조 시료 $0.2 \mathrm{~g}$ 에 $70 \%$ methanol $2 \mathrm{~mL}$ 을 가한 후 $50^{\circ} \mathrm{C}$ 에서 30 분간 초음파 추출하였다. 추출 액은 $19,872.5 \times g$ 에서 3 분간 원심분리하였으며 상층액을 $0.45 \mu \mathrm{m}$ membrane filter로 여과하여 HPLC(Agilent 1200 series, Santa Clara, CA, USA)로 분석하였다. 총 12종의 ginsenoside $\left(\mathrm{Rg}_{1}, \mathrm{Re}, \mathrm{Rf}, \mathrm{Rg}_{2}, \mathrm{Rb}_{1}, \mathrm{Rc}, \mathrm{Rb}_{2}, \mathrm{Rd}, \mathrm{F}_{2}, \mathrm{Rg}_{3}\right.$, $\mathrm{CK}, \mathrm{Rh}_{2}$ )를 분석하였으며 $\mathrm{HPLC}$ 분석조건은 다음과 같다. 컬럼은 Prodigy ODS- 2 column $(3.2 \times 250 \mathrm{~mm}, 5 \mu \mathrm{m}$, Phenomenex, Torrance, CA, USA)였으며, 검출기는 photodiode array detector를 사용하여 $202 \mathrm{~nm}$ 에서 측정하였다. 유속은 분당 $1 \mathrm{~mL}$, 시료 주입량은 $20 \mu \mathrm{L}$ 이었다. 이동상은 acetonitrile과 water를 이용하여 Table 1 과 같은 gradient 조 건에서 분석한 다음 ginsenoside 표준용액과의 retention time, 200-600 nm 범위에서의 spectrum pattern과 peak area 를 비교하여 정성 및 정량 분석하였다.
VT, USA)를 이용하여 $517 \mathrm{~nm}$ 에서 흡광도를 측정하였다. Gallic acid를 표준용액으로 이용하여 동일한 방법으로 분 석한 다음 DPPH radical 소거능을 $\mu \mathrm{g}$ of gallic acid equivalent $\mathrm{GAE}) / \mathrm{g}$ 로 나타내었다.

2,2'-Azino-bis(3-ethylbenzothiazoline-6-sulfonic acid)(ABTS) radical은 $2.4 \mathrm{mM}$ potassium persulfate에 $7 \mathrm{mM}$ $\mathrm{ABTS}$ 용액을 가한 후 냉장고에 12시간 이상 방치하여 ABTS radical cation(ABTS+)을 제조하고, $734 \mathrm{~nm}$ 에서 흡광 도 값이 $0.70 \pm 0.02$ 가 되도록 ethanol로 희석하여 사용하였 다. 희석한 $\mathrm{ABTS}+$ 용액 $950 \mu \mathrm{L}$ 와 시료 시험용액 $50 \mu \mathrm{L}$ 를 혼합하여 7분간 반응시킨 다음 다시 흡광도를 측정하여 $\mu \mathrm{g}$ of ascorbic acid equivalent(AAE)/g로 나타내었다.

환원력은 시험용액 $200 \mu \mathrm{L}$ 에 $0.2 \mathrm{M}$ sodium phosphate buffer(pH 6.6) $200 \mu \mathrm{L}$ 와 $1 \%$ potassium ferricyanide 용액 $200 \mu \mathrm{L}$ 를 차례로 가하여 $50^{\circ} \mathrm{C}$ shaking incubator에서 20 분간 반응시켰다. 반응액에 $10 \%$ trichloroacetic acid $200 \mu \mathrm{L}$ 를 가하여 반응을 중지시킨 후 $100 \mu \mathrm{L}$ 씩 취하여 증류수 100 $\mu \mathrm{L}$ 와 $0.1 \%$ ferric chloride $20 \mu \mathrm{L}$ 를 차례로 가하여 혼합한 다음 $700 \mathrm{~nm}$ 에서 흡광도를 측정하였다. 환원력은 gallic $\mathrm{acid}$ 를 표준용액으로 사용하여 $\mu \mathrm{g}$ of $\mathrm{GAE} / \mathrm{mL}$ 로 나타내었다.

\section{총 폴리페놀 함량 분석}

총 폴리페놀 함량은 Singleton 등(31)의 방법으로 분석하 였다. 동결 건조 분말 시료 $1.5 \mathrm{~g}$ 을 취하여 $50 \%$ ethanol $15 \mathrm{~mL}$ 를 가한 뒤 $50^{\circ} \mathrm{C}$ shaking incubator에서 $100 \mathrm{rpm}$ 으로 1시간 동안 추출하고 Whatman No.1(Whatman International Ltd., Maidstone, England)으로 여과한 추출액을 시험용액으 로 사용하였다. 시험용액 $40 \mu \mathrm{L}$ 를 취하고 증류수 $200 \mu \mathrm{L}$,

Table 1. Gradient condition of HPLC mobile phases for ginsenoside analysis

\begin{tabular}{cccccccccccc}
\hline Time $(\mathrm{min})$ & 0 & 20 & 23 & 42 & 55 & 64 & 73 & 75 & 78 & 83 & 89 \\
\hline $\mathrm{A}^{1)}(\%)$ & 17.5 & 21.0 & 26.0 & 26.0 & 36.0 & 50.0 & 68.0 & 80.0 & 80.0 & 17.5 & 17.5 \\
$\mathrm{~B}^{2)}(\%)$ & 82.5 & 79.0 & 74.0 & 74.0 & 64.0 & 50.0 & 32.0 & 20.0 & 20.0 & 82.5 & 82.5 \\
\hline
\end{tabular}

${ }^{1)}$ Eluent A, acetonitrile.

${ }^{2}$ Eluent B, water.

\section{항산화능 측정}

DPPH radical 소거능은 Blois(28)의 방법, ABTS radical 소거능은 Arts 등(29)의 방법, 환원력(reducing power)은 Oyaizu(30)의 방법을 변형하여 측정하였다. 동결건조 시료 를 $1.5 \mathrm{~g}$ 취하여 $50 \%$ ethanol $15 \mathrm{~mL}$ 를 가한 뒤 $50^{\circ} \mathrm{C}$ shaking incubator(HB-201SF, Han-Baek Scientific Co., Bucheon, Korea)에서 $100 \mathrm{rpm}$ 으로 1 시간 동안 추출한 다음 여과하여 시험용액으로 사용하였다.

DPPH radical 소거능은 시험용액 $60 \mu \mathrm{L}$ 에 $0.2 \mathrm{mM} \mathrm{DPPH}$ 용액 $240 \mu \mathrm{L}$ 를 가하여 잘 혼합한 후 암실에서 30 분간 방치 한 뒤 분광광도계(Eon, BioTek Instruments, Inc., Winooski,
$50 \%$ Folin-Ciocalteu's phenol reagent $20 \mu \mathrm{L}$ 를 차례로 혼합 한 다음 $5 \% \mathrm{Na}_{2} \mathrm{CO}_{3}$ 용액 $40 \mu \mathrm{L}$ 를 넣어 잘 혼합하였다. 혼합액을 1 시간 동안 암실에 방치시킨 후 분광광도계를 이용하여 $750 \mathrm{~nm}$ 에서 흡광도를 측정하였다. 총 폴리페놀 함량은 gallic acid를 표준용액으로 사용하여 $\mu \mathrm{g} \mathrm{GAE} / \mathrm{g}$ 으로 나타내었다.

\section{총 플라보노이드 함량 분석}

총 플라보노이드 함량은 Zhishen 등(32)의 방법을 이용하 여 측정하였다. 동결건조 시료를 $1.5 \mathrm{~g}$ 취하여 $50 \%$ ethanol 을 $15 \mathrm{~mL}$ 가한 뒤 $50^{\circ} \mathrm{C}$ shaking incubator에서 $100 \mathrm{rpm}$ 으로 
1 시간 동안 추출하여 여과한 추출액을 시험용액으로 사용 하였다. 시험용액 $100 \mu \mathrm{L}$ 에 $80 \%$ ethanol $400 \mu \mathrm{L}, 5 \%$ sodium nitrite $30 \mu \mathrm{L}$ 를 차례로 가하여 혼합한 뒤 실온에서 5 분간 반응시켰다. $10 \%$ aluminium chloride $30 \mu \mathrm{L}$ 와 $1 \mathrm{M}$ sodium hydroxide $200 \mu \mathrm{L}$ 를 가하여 혼합한 후 1 분간 정치한 뒤, 반응액에 증류수 $200 \mu \mathrm{L}$ 를 가하고 분광광도계로 $420 \mathrm{~nm}$ 에 서 흡광도를 측정하였다. 총 플라보노이드 함량은 $\mathrm{mg}$ of quercetin equivalent(QE)/g로 나타내었다.

\section{산성다당체 함량 분석}

산성다당체는 galacturonic acid의 polymer로 pectin과 분 자구조가 유사한 물질로 pectin 정량에 사용되는 carbazoleulfuric acid의 방법(33)으로 측정하였다. 동결건조 시료 0.1 $\mathrm{g}$ 에 증류수 $10 \mathrm{~mL}$ 을 가하여 $80^{\circ} \mathrm{C}$ shaking water bath에서 1 시간 동안 추출한 후 냉각시켰다. 추출액을 $1,413.2 \times g$ 에서 10 분간 원심분리시켰다. 상층액 $0.2 \mathrm{~mL}$ 에 무수에탄올 0.8 $\mathrm{mL}$ 을 가하여 잘 혼합한 뒤 $1,413.2 \times \mathrm{g}$ 에서 5 분간 원심분리 하여 상층액을 제거하였다. 침전물을 증류수 $1.8 \mathrm{~mL}$ 에 녹이 고 10 배 희석한 액 $50 \mu \mathrm{L}$ 에 $0.1 \%$ carbazole-ethanol 용액 $25 \mu \mathrm{L}$ 와 진한 황산 $300 \mu \mathrm{L}$ 를 가하고 잘 혼합한 뒤, $85^{\circ} \mathrm{C}$ 항온수조에서 3 분간 반응시켜 냉각시킨 후 $525 \mathrm{~nm}$ 에서 흡광도를 측정하였다. 산성다당체 함량은 $\mathrm{mg}$ of galacturonic acid equivalent(GAAE)/g로 나타내었다.

\section{Xanthine oxidase 저해활성 측정}

Xanthine oxidase 저해활성은 Noro 등(34)의 방법에 따라 측정하였다. 동결건조 시료를 $1.5 \mathrm{~g}$ 취하여 증류수 $15 \mathrm{~mL}$ 을 가한 뒤 $50^{\circ} \mathrm{C}$ shaking incubator에서 $100 \mathrm{rpm}$ 으로 1 시간 동안 추출하여 여과한(Whatman No.1, Whatman International Ltd.) 추출액을 시험용액으로 사용하였다. 시험용액 $100 \mu \mathrm{L}$ 과 $0.1 \mathrm{M}$ potassium phosphate 완충용액(pH 7.5) $600 \mu \mathrm{L}$ 을 혼합한 뒤 $2 \mathrm{mM}$ xanthine/0.1 M potassium phosphate buffer $200 \mu \mathrm{L}$ 를 첨가하였다. Xanthine을 첨가한 용액에 xanthine oxidase/water(0.2 unit $/ \mathrm{mL}) 100 \mu \mathrm{L}$ 를 가하여 잘 혼합한 후, $37^{\circ} \mathrm{C}$ 에서 30 분간 반응시켰다. 반응액의 흡광도를 분광광도 계를 이용하여 $292 \mathrm{~nm}$ 에서 측정하고 xanthine oxidase inhibitory activity(\%)으로 나타내었다.

\section{통계 분석}

각 실험은 모두 3회 이상 반복실험을 통해 결과를 얻었으 며, SPSS(Statistical Package for the Social Science Inc., Chicago, IL, USA) program version 25.0을 이용하여 통계 분석하였다. 각 항목의 평균값의 차이는 유의수준 $\mathrm{p}<0.05$ 에 서 일원분산분석법(one-way ANOVA test)을 이용하여 검 증하였고, 시료 간의 유의성은 Duncan's multiple range test 로 검정하여 분석 평가하였다.

\section{결과 및 고찰}

\section{산양삼의 형태학적 특성}

산양삼은 Fig. 1과 같이 뇌두(Rhizome), 원뿌리(Main root), 및 지근(rootlet)으로 구분할 수 있으며 뇌두로부터 가장 긴 부분의 길이를 산양심의 총 길이로 측정하였으며, 뇌두와 원뿌리의 두께, 산양삼 뿌리의 총 무게를 년근별로 측정하여 비교한 결과는 Table 2 와 같다. 뇌두의 길이는 생육기간이 증가할수록 유의적으로 증가하였으나 $(\mathrm{p}<0.05)$, 7년근과 9년근 산양삼에서는 뇌두 길이의 유의적인 차이가 관찰되지 않았다. 또한, 산양삼의 원뿌리의 길이와 총 길이 의 경우 재배 연수가 $3,5,7$ 년근으로 증가하면서 길이의 평균값이 높아졌으나 이러한 차이가 유의적이지 않은 것으 로 나타났는데 이는 같은 년근이라 하더라도 산양삼의 뿌리 별 특성에 따라 총 길이의 편차가 크게 나타나기 때문에 유의성이 없게 나타난 것으로 보인다. 한편, 산양삼 뇌두의 두께, 원뿌리 두께, 및 총 무게는 3년근보다 5년근이 약 2-3배 정도 증가하는 유의적인 차이를 나타났으나 $(\mathrm{p}<0.05)$,

Table 2. Physical characteristics of cultivated mountain ginseng with different ages

\begin{tabular}{|c|c|c|c|c|c|}
\hline \multirow{2}{*}{ Parameters } & \multirow{2}{*}{ Parts } & \multicolumn{4}{|c|}{ Cultivated mountain ginseng } \\
\hline & & 3-years & 5 -years & 7-years & 9-years \\
\hline \multirow{4}{*}{ Length } & Rhizome (cm) & $1.42 \pm 0.42^{1 / 62)}$ & $1.72 \pm 0.55^{b}$ & $2.47 \pm 0.37^{\mathrm{a}}$ & $2.53 \pm 0.62^{\mathrm{a}}$ \\
\hline & Main root $(\mathrm{cm})$ & $3.89 \pm 1.38^{\mathrm{NS} 3)}$ & $4.75 \pm 1.40$ & $5.20 \pm 2.47$ & $4.44 \pm 1.71$ \\
\hline & Rootlet $(\mathrm{cm})$ & $8.66 \pm 2.32^{\mathrm{b}}$ & $13.95 \pm 3.63^{\mathrm{a}}$ & $14.85 \pm 5.54^{\mathrm{a}}$ & $12.18 \pm 5.28^{\mathrm{ab}}$ \\
\hline & Total (cm) & $13.96 \pm 2.45^{\mathrm{b}}$ & $20.42 \pm 2.98^{\mathrm{a}}$ & $22.53 \pm 6.02^{\mathrm{a}}$ & $19.15 \pm 4.01^{\mathrm{a}}$ \\
\hline \multirow{2}{*}{ Thickness } & Rhizome (cm) & $0.39 \pm 0.09^{b}$ & $0.61 \pm 0.11^{\mathrm{a}}$ & $0.63 \pm 0.16^{\mathrm{a}}$ & $0.67 \pm 0.08^{\mathrm{a}}$ \\
\hline & Main root $(\mathrm{cm})$ & $0.68 \pm 0.07^{b}$ & $1.02 \pm 0.15^{\mathrm{a}}$ & $1.00 \pm 0.19^{a}$ & $1.01 \pm 0.16^{\mathrm{a}}$ \\
\hline \multicolumn{2}{|c|}{ Weight (g) } & $1.00 \pm 0.15^{\mathrm{b}}$ & $3.68 \pm 0.85^{\mathrm{a}}$ & $3.92 \pm 0.78^{a}$ & $3.39 \pm 0.77^{\mathrm{a}}$ \\
\hline
\end{tabular}

${ }^{1)}$ Mean \pm SD.

${ }^{2}$ Means with different superscript small letters in the same row are significantly different for the same parameter at $\mathrm{p}<0.05$ by Duncan's multiple range test.

${ }^{3} \mathrm{NS}$, not significant. 
5년근 이후부터는 재배 기간의 증가에 따른 형태학적 특성 변화가 유의적이지 않은 것으로 나타났다. 최적의 환경으 로 관리 재배되는 인삼과 달리 씨를 산에 방사하여 재배하 는 산양삼의 경우 환경 변화에 더욱 민감하여 일교차가 적은 지역과 직사광선에 덜 노출되는 지역 등 뿌려지는 부분적 자연환경에 따른 영향이 보다 크게 나타날 것으로 보이며(35) 산에서 생육되는 경우 인삼보다 생육이 더디며 모양이 곧지 않고, 지근 및 세근이 발달하는 과정에서 자연 의 영향을 더 많이 받기 때문에 뿌리의 길이나 무게와 같은 형태학적 특성에서 편차가 크게 나타나는 것으로 보인다 (36).

\section{산양삼의 일반성분 함량}

연근별 산양삼의 일반성분 함량을 측정한 결과는 Table 3 과 같다. $3,5,7,9$ 년근 산양삼의 수분 함량은 생육 기간에 따라 59.2-66.7\%의 범위를 보였는데, 생육 기간이 증가할수 록 수분함량이 감소하다가 9년근에서 증가하여 $66.72 \%$ 로 가장 높은 수분함량을 보였다. 이는 $3,5,7$ 년근 산양삼에서 연근이 증가함에 따라 수분함량이 낮아진다는 Lee 등(36) 의 연구 결과와 일치한다. 단백질 함량은 산양삼의 생육 기간이 증가할수록 그 함량이 증가하는 것으로 나타났으나 95\% 신뢰도 수준에서는 그 차이가 유의적이지 못한 것으로 나타났다. 한편, 조지방 함량도 생육기간 7년까지 회분 함 량은 생육 기간 5년까지 수치상으로는 증가하다가 이후 감소하는 것으로 나타났으나 이러한 변화정도 또한 $95 \%$ 신뢰도 수준에서는 유의적이지 않은 것으로 나타났다. 인 삼의 경우 다양한 재배 지역과 재배 연수에 따라 조단백질 함량이 달라지는 것으로 보고되었는데(37) 본 연구의 산양 삼도 이와 유사한 특성을 보이는 것으로 나타났다.

\section{산양삼의 진세노사이드 함량}

생육기간에 따른 산양삼의 진세노사이드 함량을 분석한 HPLC 크로마토그램은 Fig. 2와 같으며 각각의 함량을 분석 한 결과는 Table 6과 같다. 진세노사이드(ginsenoside)는 당 (glycone)과 비당(aglycone)이 결합한 형태인 배당체 형태로 존재하는데, 당과 결합한 형태에 따라 $\mathrm{Rb}_{1}, \mathrm{Rb}_{2}, \mathrm{Rc}, \mathrm{Rd}$, $\mathrm{F}_{2}, \mathrm{Rg}_{3}, \mathrm{Rh}_{2}$, compound $\mathrm{K}$ 인 protopanaxadiol(PPD) 그룹과 $\mathrm{Re}, \mathrm{Rf}, \mathrm{Rg}_{1}, \mathrm{Rg}_{2}$ 가 속하는 protopanaxatriol(PPT) 그룹으로 나누어진다.
총 진세노사이드 함량은 연근이 증가함에 따라 유의적인 증가를 보여, 9년근은 $(37.12 \mathrm{mg} / \mathrm{g})$ 3년근 $(13.22 \mathrm{mg} / \mathrm{g})$ 에 비 해 약 2.8 배 높은 총 함량을 보였다. PPD 그룹에서는 $\mathrm{Rb}_{1}$ 이 연근에 따라 20-29\% 함유율의 범위를 보이며 가장 높은 함량을 차지하였고, PPT 그룹에서는 Re가 23-33\%를 구성 하는 것으로 나타나 함유율이 가장 높았다. 다음으로는 $\mathrm{Rg}_{1}$ 이 $10-13 \%$ 를 차지하며 높은 함유율을 보였다. $\mathrm{Rg}_{3}$ 는 모든 시료에서 검출되지 않았으며, Lee 등(36)의 산양삼 연구에 서도 $\mathrm{Rg}_{3}$ 는 검출되지 않았다고 보고되어 본 연구 결과와 일치하였다. 한편, compound $\mathrm{K}$ 는 인삼에서는 발견되지 않 고 산삼에서만 미량 검출되는 진세노사이드로 알려져 있는 데, 본 연구 결과 모든 산양삼 연근에서 $0.01-0.03 \mathrm{mg} / \mathrm{g}$ 범위 로 미량 검출되었다. 인삼 채집시기에 따른 진세노사이드 성분의 함량을 조사한 Chang(38)은 $\mathrm{Re}, \mathrm{Rd} \mathrm{Rg}_{1}$ 이 전체 진세 노사이드 중 $70 \%$ 를 차지한다고 하였으며, $\mathrm{Nam}(39)$ 의 보고 에서는 인삼 재배조건에 따라서 조성의 차이는 있으나 $\mathrm{Rg}_{1}$, $\mathrm{Rb}_{1}, \mathrm{Rb}_{2}, \mathrm{Rc}$, 및 $\mathrm{Re}$ 가 주로 함유되어 있다고 보고하였다. Jeong 등(40)의 연구 결과에 따르면 동일한 조건에서 산양 삼은 재배 인삼에 비하여 총사포닌 함량과 $\mathrm{Rd}$ 와 $\mathrm{Re}$ 와 같은 ginsenoside 함량이 높게 나타났다고 보고하였다. 경북 영주 에서 채취한 산양삼에서는 $\mathrm{Rb}_{1}$ 의 함유율이 전체 진세노사 이드 중 약 $75 \%$ 를 차지하며 가장 높은 함량으로 보고되었 는데(41) 이는 본 연구에서 $\mathrm{Rb}_{1}$ 이 20-29\%를 차지한 것과는 다른 경향이라 하겠다.

한편, 지역별로 채취한 산양삼의 진세노사이드 함량을 조사한 Moon(42)의 연구에서도 각 진세노사이드의 함량이 지역별로 4-5배 정도로 큰 차이를 나타냈으며, $\mathrm{Rb}_{1}$ 도 지역 에 따라 화순은 $1.03 \mathrm{mg} / 100 \mathrm{~g}$ 의 함량을 보였지만 안동은 $0.22 \mathrm{mg} / 100 \mathrm{~g}$ 수준으로 약 4.7배의 차이를 보인다고 하였 다. 인삼류의 진세노사이드 함량은 계절이나 수확시기, 부 위별에 따라 차이가 있으며(43), 품종과 뿌리의 부위(44), 재배 지역과 년근에 따라서도 차이를 보이는 것으로 알려져 있다(45). 이 외에도, Lee 등(36)은 높은 온도에서 장시간 실행된 환류추출 방법이 상온 추출 방법보다 더 높은 진세 노사이드 수율을 보인 반면, compound $\mathrm{K}$ 는 상온 추출에서 보다 높은 함량을 보였다고 보고하여, 같은 원료라도 추출 방법에 따라 추출되는 진세노사이드 종류와 함량에 차이가 날 수 있음을 보여주었다.

Table 3. Proximate composition of cultivated mountain ginseng with different ages

\begin{tabular}{ccccc}
\hline Cultivated mountain ginseng & Crude ash (\%) & Moisture $(\%)$ & Crude protein (\%) & Crude fat $(\%)$ \\
\hline 3-years & $3.86 \pm 0.40^{1)}$ & $65.99 \pm 1.43^{\mathrm{b} 2}$ & $5.83 \pm 0.35$ & $0.39 \pm 0.00$ \\
5-years & $6.86 \pm 0.53$ & $65.01 \pm 1.48^{\mathrm{b}}$ & $6.26 \pm 0.11$ & $0.67 \pm 0.18$ \\
7-years & $5.13 \pm 0.08$ & $59.19 \pm 3.75^{\mathrm{c}}$ & $7.97 \pm 0.46$ & $1.18 \pm 0.43$ \\
9-years & $4.21 \pm 0.01$ & $66.72 \pm 0.18^{\mathrm{ab}}$ & $8.97 \pm 1.36$ & $0.91 \pm 0.23$ \\
\hline
\end{tabular}

${ }^{2)}$ Means with different superscript small letters in the same column are significantly different at $p<0.05$ by Duncan's multiple range test. 
(A)

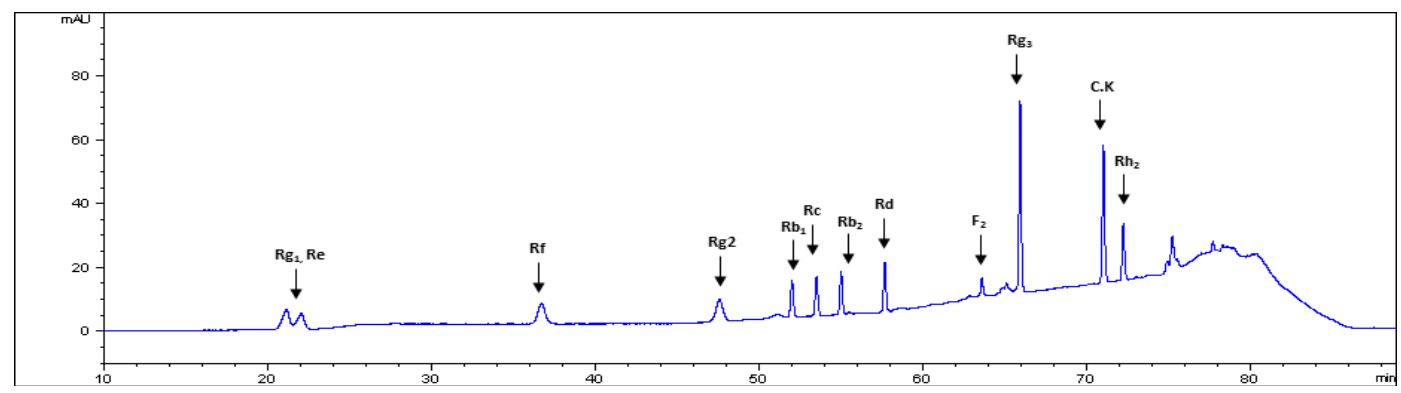

(B)

(C)
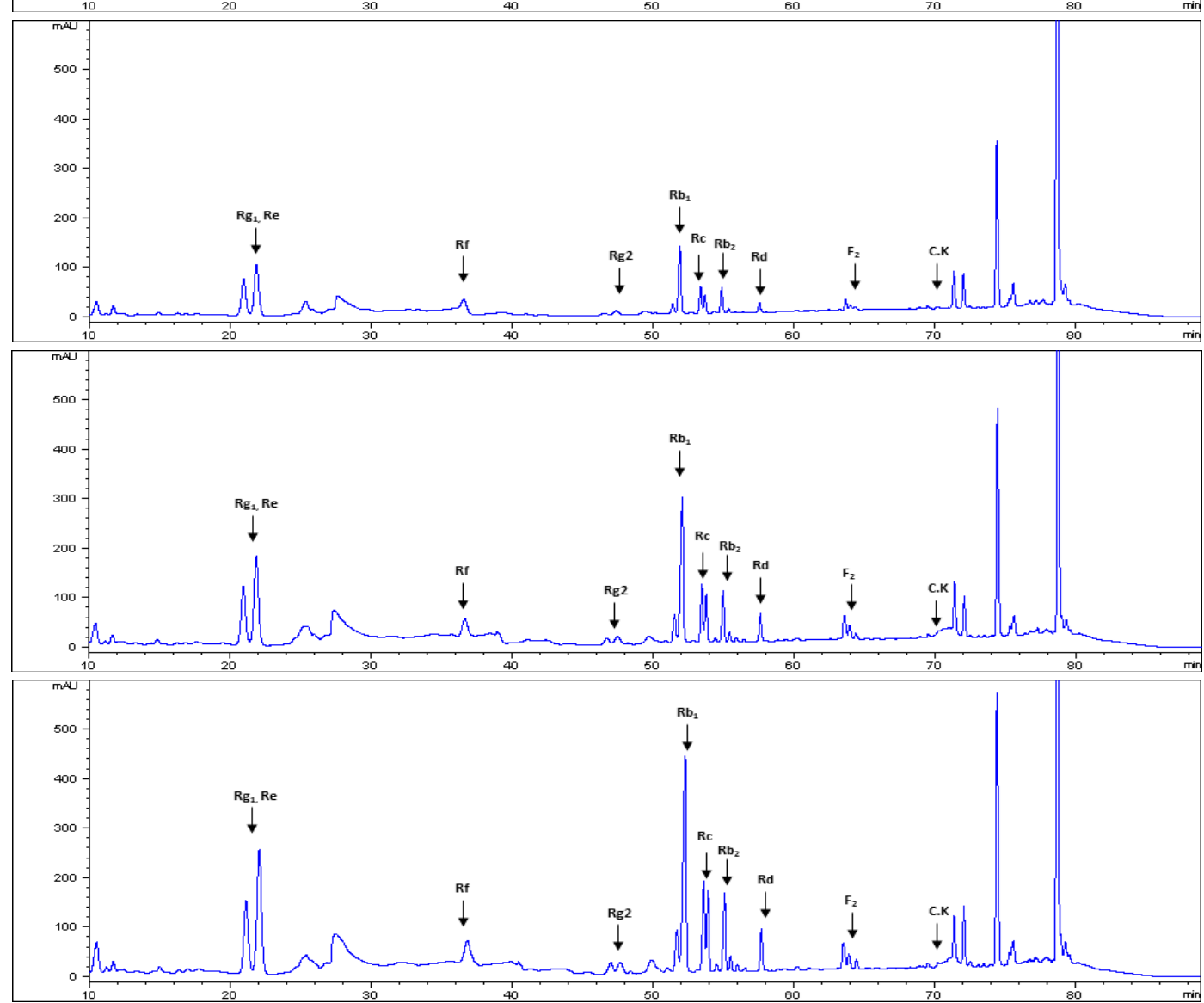

(D)

(E)

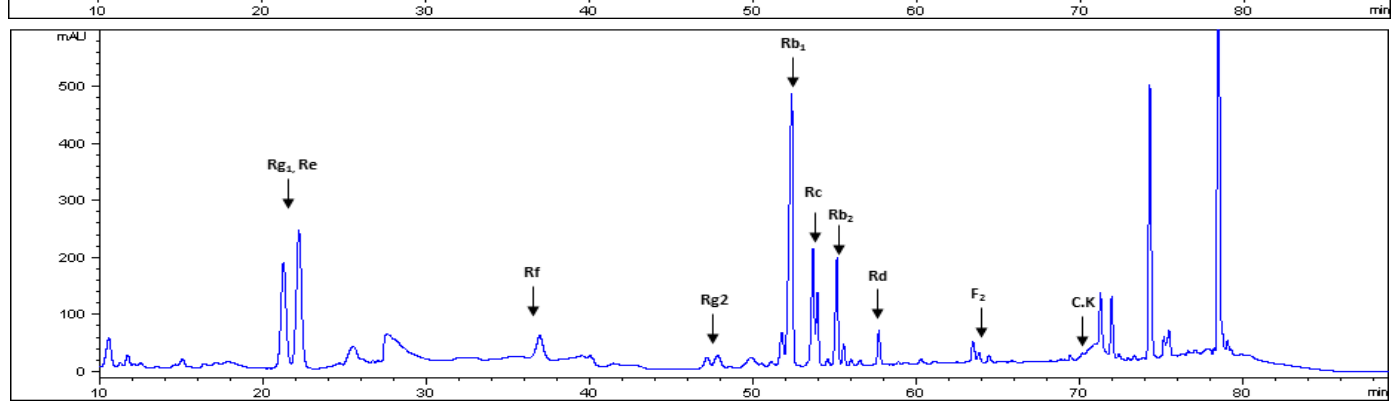

Fig. 2. HPLC chromatograms of ginsenosides in cultivated mountain ginseng.

(A): ginsenosdie standard $\left(\mathrm{Rg}_{1}, \mathrm{Re}, \mathrm{Rf}, \mathrm{Rg}_{2}, \mathrm{Rb}_{1}, \mathrm{Rc} \mathrm{Rb} 2, \mathrm{Rd}, \mathrm{F}_{2}, \mathrm{Rg}_{3}\right.$, compound $\left.\mathrm{K}, \mathrm{Rh}_{2}\right)$. (B), (C), (D), and (E) indicate 3-, 5-, 7-, and 9-years-old cultivated mountain ginseng samples, respectively.

산양삼의 총 진세노사이드 함량은 연근수가 증가함에 따라 증가하였는데, 이와 함께 $\mathrm{Rd}$, compound $\mathrm{K}, \mathrm{Rg}_{2}$ 를 제외 한 개별 진세노사이드 함량도 대체적으로 연근수에 따라 증가하는 것으로 나타났으며 총 진세노사이드 함량에서
각 진세노사이드 함량이 차지하고 있는 구성 비율은 큰 차이를 보이지 않아 비교적 일정하게 유지되는 것으로 보여 진다. 이와 달리, $\operatorname{Re}$ 는 어린 3 년근에서 $33 \%$ 로 가장 높은 비율을 보였으나 이후 연근수가 증가하면서 유의적으로 
낮아져 $(\mathrm{p}<0.05)$ 9년근에서는 $23 \%$ 로 가장 낮은 구성비를 나타냈다. 이와 달리 강원도 평창산 산양삼을 $3,5,7$ 년근별 로 진세노사이드 함량을 분석한 Lee 등(36)은 시료 중 7년근 이 진세노사이드 함량이 가장 높았으나 5년근에서 가장 낮은 진세노사이드 함량을 보였다고 하여 지역별로 차이가 있는 것으로 보여진다.

\section{산양삼의 항산화능 및 xanthine oxidase 저해활성}

산양삼의 항산화능은 DPPH radical 소거능, $\mathrm{ABTS}$ radical 소거능, 환원력(reducing power)을 측정하였으며 결과는 다 음과 같다(Table 4). 산양삼의 DPPH radical 소거능의 경우 9년근이 $82.37 \mu \mathrm{g} \mathrm{GAE} / \mathrm{mL}$ 로 가장 높게 나타났으며 이후 3 년근 > 7년근 > 5년근 순으로 높은 수치를 보였다. ABTS radical 소거능에서도 9년근이 $723.63 \mu \mathrm{g} \mathrm{AAE} / \mathrm{mL}$ 으로 가장 높은 항산화능을 보였으나 이후 5 년근 > 3 년근 > 7년근 순으로 나타나 DPPH radical 소거능과는 다소 다른 결과를 보였다. Lee 등(36)은 $3,5,7$ 년근 산양삼의 항산화능 측정 결과에서 3년근이 DPPH 및 ABTS radical 소거능이 가장 높았으며 5년근과 7년근은 유의적인 차이가 없었다고 보고 하여, 본 실험과는 다른 결과를 보였다. 한편, 산양삼의 환원 력은 3년근이 $411.69 \mathrm{\mu g} \mathrm{GAE} / \mathrm{mL}$ 로 가장 높게 나타났으며 5 년근이 가장 낮게 나타났다. DPPH radical과 ABTS radical 소거능 측정은 모두 시험관에서 인위적으로 radical을 생성 시킨 후 시료와 혼합하여 시료 중의 항산화 물질에 의해 소거되는 radical에 의한 색의 변화를 측정한다는 점에서
유사하나 DPPH는 음이온 라디컬을 ABTS는 양이온 라디 컬을 소거하는 원리로 측정되기 때문에 기질에 따라 반응하 는 페놀성 물질의 종류에 차이가 나타나게 된다(46).

산양삼의 xanthine oxidase 저해활성은 $3,5,7$ 년 근에서는 11.7-13.2\% 범위를 보이다가 9년근에서 $17.2 \%$ 로 유의적으 로 가장 높은 저해활성을 나타냈다. Xanthine oxidase는 생 체 내 퓨린 대사에 관여하는 효소로, xanthine 혹은 hypoxanthine 으로부터 urate를 형성한다. 혈장 내 urate 농도 가 증가되어 골절에 축적되면 심한 통증을 유발하기 때문 에, xanthine oxidase 저해 활성은 통풍과 관련한 질환에서 중요한 역할을 하는 것으로 알려져 있다(47).

\section{산양삼의 총 폴리페놀 및 총 플라보노이드 함량}

연근별 산양삼의 총 폴리페놀, 총 플라보노이드 함량을 분석한 결과는 Table 5 와 같다. 산양삼의 총 폴리페놀 함량 은 3 년근에서 가장 낮은 함량을 보인 후 5년근으로 생육기 간이 증가함에 따라 큰 폭으로 증가하여 $995.94 \mu \mathrm{g} \mathrm{GAE} / \mathrm{g}$ 으 로 가장 높은 함량을 나타냈으며, 이후 7년근 및 9 년근으로 재배기간이 길어지면서 유의적으로 감소하는 것으로 나타 났다. Lee 등(36)의 연구에서는 산양삼 3년근이 가장 높은 폴리페놀 함량을 보인 후 연근수가 증가함에 따라 총 폴리 페놀 함량이 점차 감소하였다고 보고하였다. 한편, Jang 등(46)의 연구에서 인삼 추출물 $1 \mathrm{mg}$ 이 $11.96 \mathrm{nmol}$ gallic acid의 폴리페놀 함량을 보인 반면 산양삼 추출물은 이보다 약 3 배 높은 34.81 nmol gallic acid 함량을 나타냈다고 하였다.

Table 4. Antioxidant and xanthine oxidase inhibition activities of cultivated mountain ginseng with different ages

\begin{tabular}{ccccc}
\hline Activities & \multicolumn{4}{c}{ Cultivated mountain ginseng } \\
\cline { 2 - 5 } & 3-years & 5-years & 7 -years & 9-years \\
\hline DPPH radical scavenging $(\mu \mathrm{g} \mathrm{GAE} / \mathrm{g})^{1)}$ & $69.65 \pm 2.49^{33) \mathrm{b})}$ & $52.09 \pm 1.97^{\mathrm{d}}$ & $64.14 \pm 1.48^{\mathrm{c}}$ & $82.37 \pm 2.44^{\mathrm{a}}$ \\
ABTS radical scavenging $(\mu \mathrm{g} \mathrm{AAE} / \mathrm{g})^{2)}$ & $609.13 \pm 16.13^{\mathrm{c}}$ & $667.90 \pm 8.36^{\mathrm{b}}$ & $606.92 \pm 14.92^{\mathrm{c}}$ & $723.63 \pm 3.06^{\mathrm{a}}$ \\
Reducing power $(\mu \mathrm{g} \mathrm{GAE} / \mathrm{g})$ & $411.69 \pm 19.09^{\mathrm{a}}$ & $347.25 \pm 4.09^{\mathrm{c}}$ & $365.87 \pm 10.27^{\mathrm{b}}$ & $365.76 \pm 10.81^{\mathrm{b}}$ \\
Xanthine oxidase inhibition $(\mu \mathrm{g} \mathrm{AAE} / \mathrm{g})$ & $12.60 \pm 0.51^{\mathrm{db}}$ & $13.21 \pm 0.45^{\mathrm{b}}$ & $11.70 \pm 0.40^{\mathrm{c}}$ & $17.24 \pm 0.15^{\mathrm{a}}$ \\
\hline
\end{tabular}

${ }^{1)} \mu \mathrm{g}$ gallic acid equivalent/g.

${ }^{2)} \mathrm{ug}$ ascorbic acid equivalent/g.

${ }^{3)}$ Mean \pm SD.

${ }^{4}$ Means with different superscript small letters in the same row are significantly different at $p<0.05$ by Duncan's multiple range test.

Table 5. The contents of total polyphenol, total flavonoid, and acidic polysaccharide of cultivated mountain ginseng with different ages

\begin{tabular}{ccccc}
\hline \multirow{2}{*}{ Parameters } & \multicolumn{4}{c}{ Cultivated mountain ginseng } \\
\cline { 2 - 5 } & 3-years & 5-years & 7-years & 9-years \\
\hline Total polyphenol content ( $\mathrm{gg} \mathrm{GAE} / \mathrm{g})$ & $807.43 \pm 39.99^{3) \mathrm{d} 4)}$ & $995.94 \pm 21.50^{\mathrm{a}}$ & $934.91 \pm 6.27^{\mathrm{b}}$ & $880.25 \pm 39.14^{\mathrm{c}}$ \\
Total flavonoid content (mg QE/g) & $3.78 \pm 0.16^{\mathrm{a}}$ & $3.80 \pm 0.13^{\mathrm{a}}$ & $3.89 \pm 0.13^{\mathrm{a}}$ & $3.44 \pm 0.25^{\mathrm{b}}$ \\
Acidic polysaccharide content (mg GAAE/g) & $2,569.15 \pm 99.38^{\mathrm{c}}$ & $3,173.75 \pm 22.75^{\mathrm{b}}$ & $3,297.99 \pm 30.82^{\mathrm{a}}$ & $3,177.76 \pm 74.11^{\mathrm{b}}$ \\
\hline
\end{tabular}

${ }^{1)} \mu \mathrm{g}$ quercetin equivalent/g.

2) $\mu \mathrm{g}$ galacturonic acid equivalent/g.

${ }^{3)}$ Mean \pm SD.

${ }^{4}$ Means with different superscript small letters in the same row are significantly different at $\mathrm{p}<0.05$ by Duncan's multiple range test. 
연근별 산양삼의 총 플라보노이드 함량은 3년근에서 7년 근까지 3.78-3.89 mg QE/g으로 유의적인 함량 차이가 없었 으나 9년근에서 $3.44 \mathrm{mg} \mathrm{QE} / \mathrm{mL}$ 로 유의적인 감소를 보였다. 산양삼 $3,5,7$ 년근의 총 플라보노이드 함량을 연구 보고한 Lee 등(36)에 따르면, 3 년근이 가장 높은 플라보노이드 함 량을 보인 후 생육기간이 지남에 따라 함량이 감소한다고 보고하여 대체적으로 재배 기간이 짧은 어린 연근일수록 항산화 성분의 함량이 높지만 재배 연수가 길어지면서 이러 한 성분들이 차츰 감소하는 것으로 보여진다.

폴리페놀과 플라보노이드는 식물에 존재하는 대표적인 항산화 물질로 산화-환원 반응에서 기질로 작용하며, 다양 한 생리활성을 가지는 것으로 알려져 있는데(46,48), 인삼 류의 경우 salicylic acid, p-benzoxy-benzic acid, gentisic acid, vanillic acid 등을 포함한 10여종 이상의 페놀성 화합물이 존재하는 것으로 보고되어 있다(49,50). Ok 등(51)은 에탄 올로 추출한 산양삼 추출물이 열수추출보다 약 2 배 높은 총 플라보노이드 함량을 나타냈다고 보고하였으며, Yoo 등(52)은 인삼의 서식지 및 재배 방법에 따라서도 페놀성 성분 및 함량에 차이를 보인다고 하였다. 이와 같이 폴리페 놀과 플라보노이드 함량은 추출법에 따라 같은 시료라도 다르게 나타날 수 있으며, 재배 지역에 따라서도 다르게 나타날 수 있다. 이는 Moon(42)의 안동, 화순, 서천, 홍천의 지역별 산양삼의 특성 연구에서 서식지에 따라 페놀성 화합 물 개체의 검출 여부 및 함량에 큰 차이가 나타났다고 보고 한 것과 일치한다.

\section{산양삼의 산성다당체 함량}

산양삼의 년근별 산성다당체 함량을 분석한 결과는 Table 5 과 같다. 본 연구에서 산양삼의 연근별 산성다당체 함량은 생육기간이 증가할수록 유의적으로 증가하는 경향 을 보였는데, 7년근이 $3,297.99 \mathrm{mg} \mathrm{GAAE} / \mathrm{g}$ 로 가장 높은 함량을 보였고, 9년근은 다소 감소하는 것으로 나타났다. 산성다당체는 galacturonic acid, glucuronic acid, mannuronic acid 등의 산성당이 다량 함유된 분자량 $10,000-15,000$ 이상 의 다당체를 말하며 중성다당체에 비해 면역 증진 효과가 크다고 알려져 있다(53). 한편, Lee 등(35)은 평창산 3,5 , 7년근 산양삼에서는 산성다당체 함량이 3년근에서 2,419 $\mathrm{mg} \mathrm{GAAE} / \mathrm{g}$ 으로 가장 높은 함량을 보였고 재배 연수가 증가할수록 유의적으로 감소한다고 보고하여 본 연구와는 상반된 결과를 보여주었다. Lee 등(35)은 낮은 연령근일수 록 건조중량 당 산성다당체의 양이 많은 것은 산성다당체 생합성량이 부피 성장보다 커서 단위 중량당 산성다당체의 함량이 많다고 하였으며 이는 연령이 높아질수록 산성다당 체 함량이 감소한다고 보고하였다.

\section{요 약}

본 연구는 경상남도 함양산 산양삼의 생육기간 $(3,5,7$, 9년근)에 따른 형태학적 차이, 영양성 및 기능성을 비교 분석하여 산양삼의 가공식품 산업화를 위한 기초자료로 활용하고자 하였다. 산양삼의 길이와 두께에서는 3 년근이

Table 6. Ginsenoside contents of cultivated mountain ginseng with different ages

\begin{tabular}{|c|c|c|c|c|c|}
\hline & \multirow{2}{*}{ Ginsenosides } & \multicolumn{4}{|c|}{ Ginsenoside contents of cultivated mountain ginseng (mg/g) } \\
\hline & & 3-years & 5 -years & 7 -years & 9-years \\
\hline \multirow{8}{*}{ PPD } & $\mathrm{Rb}_{1}$ & $2.75 \pm 0.38^{1 \mathrm{Db} b 2)}$ & $8.34 \pm 0.47^{\mathrm{cb}}$ & $9.09 \pm 0.18^{\mathrm{Ba}}$ & $11.12 \pm 0.47^{\mathrm{Aa}}$ \\
\hline & $\mathrm{Rb}_{2}$ & $1.15 \pm 0.18^{\mathrm{Cd}}$ & $2.83 \pm 0.17^{\mathrm{Bc}}$ & $2.93 \pm 0.03^{\mathrm{Be}}$ & $3.90 \pm 0.19^{\mathrm{Ad}}$ \\
\hline & $\mathrm{Rc}$ & $1.21 \pm 0.18^{\mathrm{Dd}}$ & $2.86 \pm 0.14^{\mathrm{Cc}}$ & $3.26 \pm 0.03^{\mathrm{Bd}}$ & $4.15 \pm 0.19^{\mathrm{Ad}}$ \\
\hline & $\mathrm{Rd}$ & $0.30 \pm 0.04^{\text {Def }}$ & $1.13 \pm 0.08^{\mathrm{Af}}$ & $1.01 \pm 0.02^{\mathrm{Bh}}$ & $0.81 \pm 0.04^{\mathrm{Cg}}$ \\
\hline & $\operatorname{Rg}_{3}$ & $\mathrm{ND}^{3 / \mathrm{N} S 4) \mathrm{f}}$ & $N D^{h}$ & $\mathrm{ND}^{\mathrm{j}}$ & $\mathrm{ND}^{\mathrm{h}}$ \\
\hline & $\mathrm{F}_{2}$ & $0.13 \pm 0.03^{\mathrm{Cf}}$ & $0.27 \pm 0.15^{\mathrm{Ag}}$ & $0.35 \pm 0.01^{\mathrm{Ai}}$ & $0.21 \pm 0.01^{\mathrm{Bh}}$ \\
\hline & Compound $\mathrm{K}$ & $0.01 \pm 0.00^{\mathrm{Cf}}$ & $0.02 \pm 0.00^{\mathrm{Bh}}$ & $0.03 \pm 0.00^{\mathrm{Aj}}$ & $0.02 \pm 0.00^{\mathrm{Bh}}$ \\
\hline & $\mathrm{Rh}_{2}$ & $\mathrm{ND}^{\mathrm{NSf}}$ & $N D^{h}$ & $\mathrm{ND}^{\mathrm{j}}$ & $\mathrm{ND}^{\mathrm{h}}$ \\
\hline \multirow{4}{*}{ PPT } & $\operatorname{Re}$ & $4.37 \pm 0.39^{\mathrm{Ca}}$ & $8.71 \pm 0.23^{\mathrm{Aa}}$ & $8.07 \pm 0.10^{\mathrm{Bb}}$ & $8.63 \pm 0.34^{\mathrm{Ab}}$ \\
\hline & $\mathrm{Rf}$ & $1.09 \pm 0.11^{\mathrm{Bd}}$ & $2.03 \pm 0.16^{\mathrm{Ad}}$ & $2.27 \pm 0.06^{\mathrm{Af}}$ & $2.40 \pm 0.55^{\mathrm{Ae}}$ \\
\hline & $\operatorname{Rg}_{1}$ & $1.74 \pm 0.21^{\mathrm{Dc}}$ & $3.05 \pm 0.10^{\mathrm{Cc}}$ & $3.75 \pm 0.16^{\mathrm{Bc}}$ & $4.81 \pm 0.12^{\mathrm{Ac}}$ \\
\hline & $\operatorname{Rg}_{2}$ & $0.59 \pm 0.05^{\mathrm{Ce}}$ & $1.46 \pm 0.09^{\mathrm{Ae}}$ & $1.28 \pm 0.02^{\mathrm{Bg}}$ & $1.29 \pm 0.09^{B f}$ \\
\hline \multicolumn{2}{|r|}{ Total } & $13.36 \pm 1.57^{\mathrm{C}}$ & $30.80 \pm 1.06^{\mathrm{B}}$ & $32.03 \pm 0.40^{B}$ & $37.34 \pm 1.97^{\mathrm{A}}$ \\
\hline
\end{tabular}

${ }^{1)}$ Mean \pm SD.

${ }^{2)}$ Means with different superscript small letters in the same column and capital letters in the same row are significantly different at $p<0.05$ by Duncan's multiple range test.

${ }^{3)} \mathrm{ND}$, not detected.

${ }^{4)} \mathrm{NS}$, not significant. 
유의적으로 짧고 가늘었으나, 5, 7, 9년근 사이에서는 유의 적인 차이를 보이지 않았다. 총 페놀함량은 5년근이 가장 높은 함량을 보이다가 이후 감소하는 경향을 보였지만, 가 장 낮은 함량은 3 년근에서 관찰되었다. 총 플라보노이드 함량의 경우, 년근수와 함께 유의적으로 감소하여 9 년근이 가장 낮은 함량을 나타내었다. 산성다당체 함량은 3년근이 유의적으로 가장 낮았으며 연근수가 증가할수록 증가하였 다. DPPH 및 ABTS 라디칼 소거능에서는 9년근에서 가장 높은 항산화능을 보인 반면 환원력에서는 3 년근이 가장 높게 나타났다. 총 진세노사이드 함량에서는 연근수가 증 가할수록 증가하는 경향을 보여, 9년근이 가장 높은 함량을 보였다. $\mathrm{Rb}_{1}$ 과 $\mathrm{Re}$ 가 전체 진세노사이드에서 비교적 높은 비율을 차지하였고, 인삼에서 발견되지 않고 산삼에서만 검출되는 compound $\mathrm{K}$ 와 같은 진세노사이드가 $0.05-0.10 \%$ 의 낮은 비율로 검출되었다. 본 연구에서 산양삼은 서식지 및 재배 조건에 따라 진세노사이드를 포함한 기능성 성분들 의 함량에 차이를 크게 보이므로, 향후 산양삼 산업화를 위해서는 보다 다양한 지역의 산양삼의 연 근별 형태학적 특성, 영양성 및 기능성에 대한 비교 연구의 축적이 필요할 것으로 생각된다.

\section{감사의 글}

본 연구는 2017년도 중소기업청의 첫걸음과제 연구비 지원(C0532814)으로 수행되었으며 이에 감사드립니다.

\section{References}

1. Park JK, Nam KY, Hyun HC, Jin SH, Chepurnov SA, Chepurnova NE (1994) Effect of red ginseng triol saponin fractions on the spatial memory function studied with 12-arm radial maze. Korean J Ginseng Sci, 18, 32-38

2. Liu WK, Xu SX, Che CT (2000) Anti-proliferative effect of ginseng saponins on human prostate cancer cell line. Life Sci, 67, 1297-1306

3. Li C, Cai J, Geng J, Li Y, Wang Z, Li R (2012) Purification, characterization and anticancer activity of a polysaccharide from Panax ginseng. Int $\mathrm{J}$ Biol Macromol, 51, 968-973

4. Lai DM, Tu YK, Liu IM, Chen PF, Cheng JT (2006) Mediation of $\beta$-endorphin by ginsenoside Rh2 to lower plasma glucose in streptozotocin-induced diabetic rats. Planta Med, 72, 9-13

5. Song JH, Park MJ, Kim E, Kim YC (1990) Effects of Panax ginseng on galactosamine-induced cytotoxicity in primary cultured rat hepatocytes. J Pharm Soc Korea, 34, 341-347

6. Kang SY, Schini-Kerth VB, Kim ND (1995) Ginsenosides of the protopananaxatriol group cause endothelium-dependent relaxation in the rat aorta. Life Sci, 56, 1577-1586

7. Kim CC (1979) Influence of Panax ginseng on the response of stressful stimuli in the experimental animal exposed to various stress. Korean J Ginseng Sci, 3, 168-186

8. Kim YK, Guo Q, Packer L (2002) Free radical scavenging activity of red ginseng aqueous extracts. Toxicol, 172, 149-156

9. Abdel-Wahhab MA, Ahmed HH (2004) Protective effect of Korean Panax ginseng against chromium VI toxicity and free radicals generation in rats. J Ginseng Res, 28, $11-17$

10. Park CK, Kwak YS, Hwang MS, Kim SC, Do JH (2007) Current status of ginseng (red ginseng) products in market of health functional food. The Korean Ginseng Research and Industry, 1, 9-16

11. Hong HD, Park HJ, Jeong JK, Jang DJ (2008) Surveys of domestic and foreign patents for process food related ginseng. J Ginseng Res, 32, 135-149

12. Hyun DY, Hyeon GS, Yeon BY, Kang SW, Kim YC, Lee KW, Kim SM (2009) A guideline to land suitability used soil physical characteristics and yield potential in Panax ginseng C.A. Mayer. Korean J Medicinal Crop Sci, 17, 421-426

13. Li X, Kang SJ, Han JS, Kim JS, Choi JE (2010) Comparison of growth increment and ginsenoside content in different parts of ginseng cultivated by direct seeding and transplanting. Korean J Medicinal Crop Sci, 18, 70-73

14. Ahn YM, Park HS, Kwon KR (2007) Anti-cancer and anti-oxidant efficacies of wild ginseng and cultivated wild ginseng of Korea and China. J Pharmacopuncture, 10, 5-16

15. Hong JY, Shin SR, Bae MJ, Bae JS, Lee IC, Kwon OJ, Jung JW, Kim YH, Kim TH (2010) Pancreatic lipase inhibitors isolated from the leaves of cultivated mountain ginseng (Panax ginseng). Korean J Food Preserv, 17, 727-732

16. Bae MJ, Kim SJ, Ye EJ, Nam HS, Park EM (2009) Antioxidant activity of tea made from Korean mountain-cultivated ginseng leaves and its influence on lipid metabolism. Korean J Food Culture, 24, 77-83

17. National Institute of Forest Science (2016) Manual for 
Analysis of Cultivated Mountain Ginseng Pharmaceutical Components. National Institute of Forest Science, Daejeon, Korea, p 5, 10

18. Lui JH, Staba EJ (1980) The ginsenosides of various ginseng plants and selected products. J Nat Prod, 43, 340-346

19. Korea Forest Service (2015) Statistical yearbook of forestry. $45^{\text {th }}$ ed, Korea Forest Service, Daejeon, Korea, p 239

20. Korea Forest Service (2017) Statistical yearbook of forestry. $47^{\text {th }}$ ed, Korea Forest Service, Daejeon, Korea, p 241

21. Gil J, Um Y, Byun JK, Chung JW, Lee Y, Chung CM (2017) Genetic diversity analysis of wood-cultivated ginseng using simple sequence repeat markers. Korean J Medicinal Crop Sci, 25, 389-396

22. Akao T, Kanaoka M, Kobashi K (1998) Appearance of compound $\mathrm{K}$, a major metabolite of ginsenoside $\mathrm{Rb} 1$ by intestinal bacteria, in rat plasma after oral administration: measurement of compound $\mathrm{K}$ by enzyme immunoassay. Biol Pharm Bull, 21, 245-249

23. Quan LH, Liang Z, Kim HB, Kim SH, Kim SY, Noh YD, Yang DC (2008) Conversion of ginsenoside Rd to compound $\mathrm{K}$ by crude enzymes extracted from Lactobacillus brevis LH8. J Ginseng Res, 32, 226-231

24. Zhou W, Feng MQ, Li JY, Zhou P (2006) Studies on the preparation, crystal structure and bioactivity of ginsenoside compound K. J Asian Nat Prod Res, 8, 519-527

25. Park CK, Jeon BS, Yang JW (2003) The chemical components of Korean ginseng. Food Industry and Nutrition, 8, 10-23

26. AOAC (2000) Offical Methods of Analysis. $17^{\text {th }}$ ed, Association of official Analutical Chemists, Gaithersburg, MD, USA, p 1-26

27. Lee KH, Lee DY, Lee SE, Nam KY, Hwang GB, Kim HD, Lee JW, Choi JH, Ahn YS, Kim SY, Kim GS (2016) Evaluation on extraction conditions and HPLC analysis method for ginsenosides in Panax ginseng. Korean $\mathrm{J}$ Medicinal Crop Sci, 24, 47-54

28. Blois MS (1958) Antioxidant determinations by the use of a stable free radical. Nature, 181, 1199-1200

29. Arts MJTJ, Haenen GRMM, Voss HP, Bast A (2004) Antioxidant capacity of reaction products limits the applicability of the trolox equivalent antioxidant capacity (TEAC) assay. Food Chem Toxicol, 42, 45-49

30. Oyaizu M (1986) Studies on products of browning reaction: Antioxidative activity of products of browning reaction prepared from glucosamine. Jpn J Nutr, 44, 307-315

31. Singleton VL, Orthofer R, Lamuela-Raventos RM (1999) Analysis of total phenols and other oxidation substrates and antioxidants by means of Folin-Ciocalteu reagent. Methods Enzymol, 299, 152-178

32. Zhishen J, Mengcheng T, Jianming W (1999) The determination of flavonoid contents in mulberry and their scavenging effects on superoxide radicals. Food Chem, 64, 555-559

33. Do JH, Lee HO, Lee SK, Jang JK, Lee SD, Sung HS (1993) Colorimetric determination of acidic polysaccharide from Panax ginseng, its extraction condition and stability. Korean J Ginseng Sci, 17, 139-144

34. Noro T, Oda Y, Miyase T, Ueno A, Fukushima S (1983) Inhibitors of xanthine oxidase from the flowers and buds of Daphne genkwa. Chem Pharm Bull, 31, 3984-3987

35. Jung CH, Seog HM, Choi IW, Park MW, Cho HY (2006) Antioxidant properties of various solvent extracts from wild ginseng leaves. LWT-Food Sci Technol, 39, 266-274

36. Lee G, Choi GS, Lee JY, Yun SJ, Kim W, L H, Baik MY, Hwang JK (2017) Proximate analysis and antioxidant activity of cultivated wild Panax ginseng. Food Eng Prog, 21, 208-214

37. Yang BW, Im BO, Ko SK (2006) Comparison of non-saponin composition and contents in fresh ginseng roots cultivated in different areas and at various ages. J Pharm Soc Korea, 50, 215-219

38. Chang HK (1998) Changes of saponin contents in Panax ginseng leaves by different harvesting months. Korean J Food Nutr, 11, 82-86

39. Nam KY (1996) The new Korean ginseng (constituent and its pharmacological efficacy). Korea Ginseng and Tabacco Research Institute, Daejeon, Korea, p 1-10

40. Jeong HS, Lim CS, Cha BC, Choi SH, Kwon KR (2010) Component analysis of cultivated ginseng, cultivated wild ginseng, and wild ginseng and the change of ginsenoside components in the process of red ginseng. J Pharmacopuncture, 13, 63-77

41. Kang KM, Lee JY, Kim MU, Lee SH (2016) Effects of quality characteristics and antioxidant activity of Korean cultivated wild gnseng extract. J Korean Soc Food Sci Nutr, 45, 1740-1746

42. Moon HK (2015) Quality characteristics and anti-diabetic effect of mountain-cultivated ginseng (Sanyangsam). $\mathrm{Ph}$ D Thesis, Kyungpook National University, Korea, p 
56-57

43. Han YJ, Kwon KR, Cha BC, Kwon OM (2007) Component analysis of cultivated ginseng, cultivated wild ginseng, and natural wild ginseng by structural parts using HPLC method. J Pharmacopuncture, 10, 37-53

44. Ahn IO, Lee SS, Lee JH, Lee MJ, Jo BG (2008) Comparison of ginsenoside contents and pattern similarity between root parts of new cultivars in Panax ginseng C.A. Meyer. J Ginseng Res, 32, 15-18

45. Lee CR, Whang WK, Shin CG, Lee HS, Han ST, Im BO, Ko SK (2004) Comparison of ginsenoside composition and contents in fresh ginseng roots cultivated in Korea, Japan and China at various ages. Korean $\mathbf{J}$ Food Sci Technol, 36, 847-850

46. Jang HY, Park HS, Kwon KR, Rhim TJ (2008) A study on the comparison of antioxidant effects among wild ginseng, cultivated wild ginseng, and cultivated ginseng extracts. J Pharmacopuncture, 11, 67-78

47. Yagi K (1987) Lipid peroxides and human disease. Chem Phys Lipids, 45, 337-351
48. Beecher GR (2003) Overview of dietary flavonoids: nomenclature, occurrence and intake. J Nutr, 133, 3248S-3254S

49. Han BH, Park MH, Han YN (1981) Studies on the antioxidant components of Korean ginseng (III)-Identification of phenolic acids. Arch Pharm Res, 4, 53-58

50. Wee JJ, Park JD, Kim MW, Lee HJ (1989) Identification of phenolic antioxidant components isolated from Panax ginseng. J Korean Agric Chem Soc, 32, 50-56

51. Ok S, Kang JS, Kim KM (2016) Simultaneous analysis method for polar and non-polar ginsenosides in cultivated wild ginseng by reversed-phase HPLC-CAD. J Life Sci, 26, 247-252

52. Yoo BS, Lee HJ, Byun SY (2000) Differences in phenolic compounds between Korean ginseng and mountain ginseng. Korean J Biotechnol Bioeng, 15, 120-124

53. Srivastava R, Kulshreshtha DK (1989) Bioactive polysaccharides from plants. Phytochemistry, 28, 2877-2883 